


\title{
THE UNITED NATIONS SERIES
}

ROBERT J. KERNER, GENERAL EDITOR

SATHER PROFESSOR OF HISTORY IN THE UNIVERSITY OF CALIFORNIA

\author{
$\infty$ \\ CZECHOSLOVAKIA \\ EDITED BY ROBERT J. KERNER \\ THE NETHERLANDS \\ EDITED BY BARTHOLOMEW LANDHEER
}

POLAND

EDITED BY BERNADOTTE E. SCHMITT

\section{BELGIUM}

EDITED BY JAN-ALBERT GORIS

\section{CHINA}

EDITED BY HARLEY F. MACNAIR

\author{
Other volumes in preparation
}


P O L A N D 


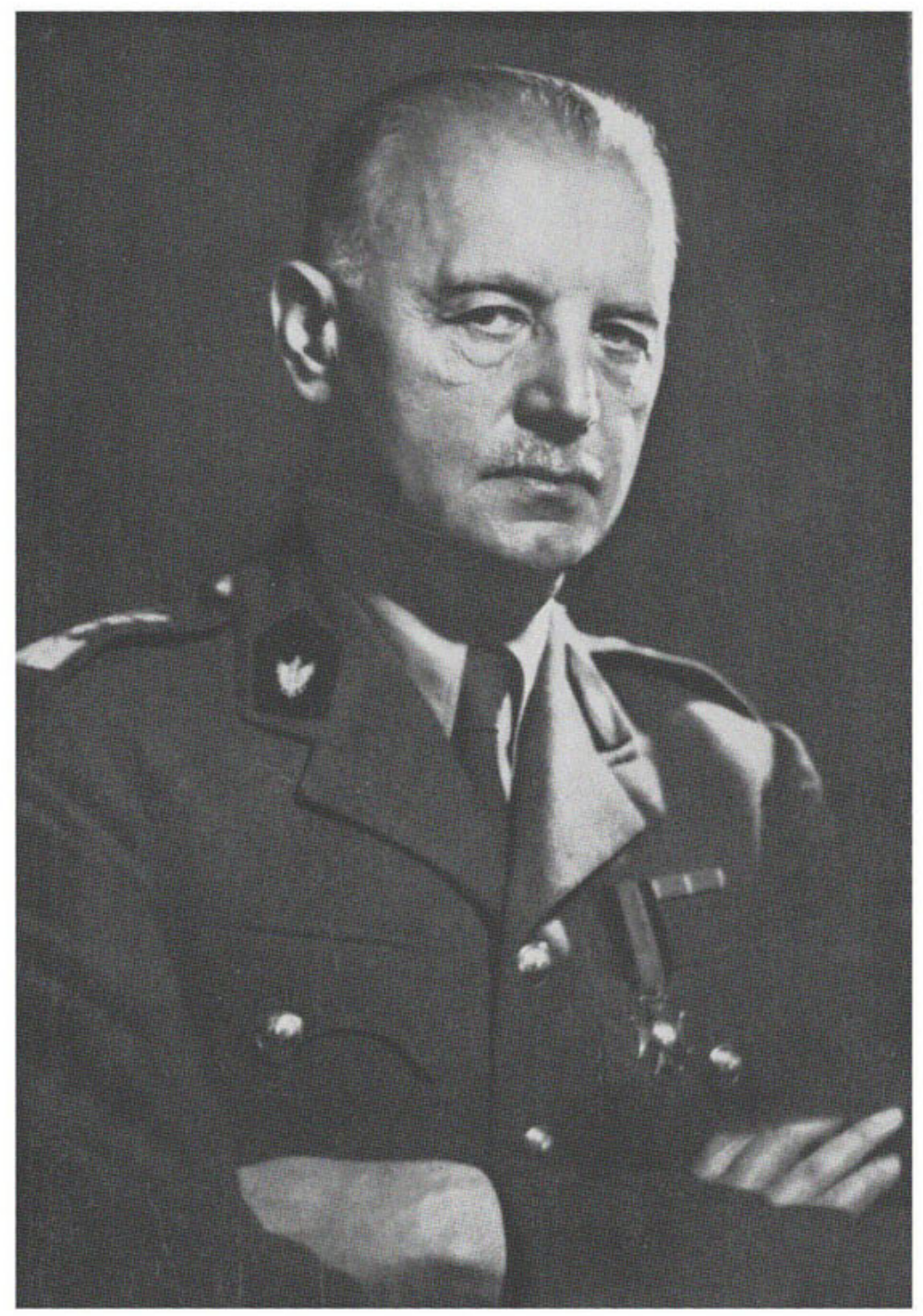

GENERAL WLADYSLAW SIKORSKI PRIME MINISTER AND COMMANDER IN CHIEF, 1939-1943 

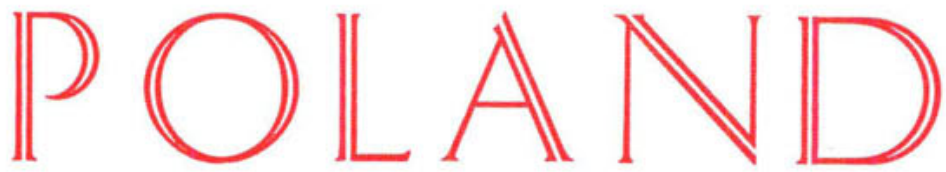

Chapters by John Lawrence Angel, Eldon R. Burke, Joseph C. Gidyński, Malbone W. Graham, Oscar Halecki, Zygmunt Karpiński, Jan K. Kasprzak, Robert J. Kerner, Manfred Kridl, Felix Roderick Labuński, Stephen P. Mizwa, Frank T. Nowak, Julia Swift Orvis, IrenaPiotrowska, Jerzy Radwan, Joseph S.Roucek,Bernadotte E.Schmitt,Stanislaw Strzetelski, Wojciech Świętosławski, S. Harrison

Thomson, Leopold Wellisz, Edmund Zawacki,

Henryk Zieliński

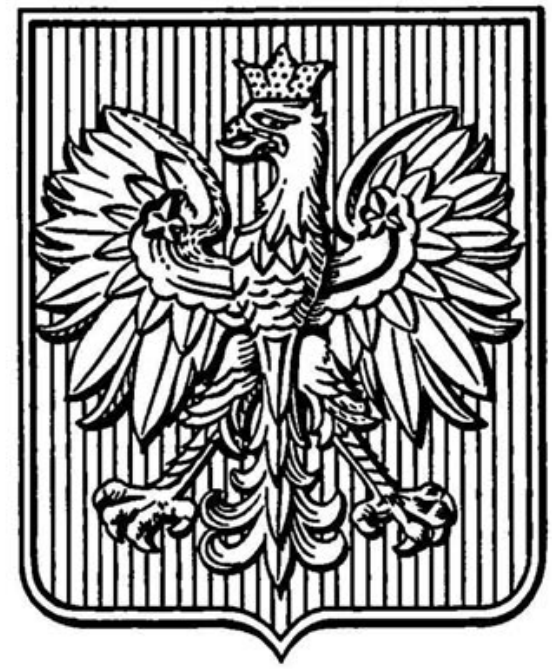

Edited by BERNADOTTE E.SCHMITT ANDREW MACLEISH DISTINGUISHED SERVICE PROFESSOR OF MODERN HISTORY IN THE UNIVERSITY OF CHICAGO

UNIVERSITY OF CALIFORNIA PRESS BERKELEY AND LOS ANGELES • 1947 
UNIYERSITY OF CALIFORNIA PRESS

BERKELEY AND LOS ANGELES

CALIFORNIA

$\infty$

CAMBRIDGE UNIYERSITY PRESS

LONDON, ENGLAND

COPYR1GHT, I945, BY

THE REGENTS OF THE UNIVERSITY OF CALIFORNIA

Second printing, 1947

PRINTED IN THE UNITED STATES OF AMERICA

gT THE UNIVERITY OF CALIFORNIA PREst 
TO THE MEMORY OF

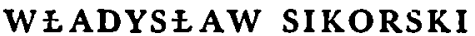

$$
\text { 1881-1943 }
$$

PATRIOT, SOLDIER, STATESMAN 
